\title{
PENGARUH PENERAPAN SISTEM INFORMASI AKUNTANSI, STANDAR AKUNTANSI KEUANGAN DAN PEMANFAATAN TEKNOLOGI INFORMASI TERHADAP KUALITAS LAPORAN KEUANGAN WAJIB PAJAK BADAN
}

\author{
Hari Purnama \\ Universitas PGRI Yogyakarta \\ e-mail : haripurnama@gmail.com
}

\begin{abstract}
This study aims to examine and analyze the effect of the application of accounting information systems, financial accounting standards and partial use of information technology on the quality of financial reports and to test and analyze the application of accounting information systems, financial accounting standards and the simultaneous use of information technology on the quality of financial reports.

The variables of this study consist of independent and dependent variables. The independent variable of this research is the application of accounting information systems, financial accounting standards and the use of information technology, the dependent variable is the quality of financial statements. The population in this study is the corporate taxpayers in the city of Yogyakarta with a sample size of 100 respondents. The sampling technique was purposive sampling. The data collection method used a questionnaire. The analysis technique used is multiple linear regression with a significance level of 5\%.

The results showed that the application of accounting information systems, financial accounting standards and the use of information technology partially had a significant effect on the quality of financial reports. Simultaneously the application of accounting information systems, financial accounting standards and the use of information technology have a significant effect on the quality of financial reports. The effect of understanding the application of accounting information systems, financial accounting standards and the use of information technology on the quality of financial reports is $23.8 \%$. The rest is influenced by other factors, namely $76.2 \%$, which were not included in this study.
\end{abstract}

Keywords: Application of Accounting Information Systems, Financial Accounting Standards, Utilization of Information Technology and Quality of Financial Statements

\section{PENDAHULUAN}

Kualitas lamporan keuangan yang dihasilkan sutu badan usaha atau perusahaan, dituntut untuk memeliki kualitas yang sesuai dengan kebutuhan laporan keuangan itu sendiri. Hal ini seiring dengan pemanfaatan teknologi informasi yang mampu memberikan kesempatan badan usaha dalam melaksanakan kewajibanya dalam 
melaporakan hasil usahanya dapat dimanfaatkan oleh pihak-pihak yang berkepentingan. Hal ini karena dengan laporan keuangan yang berkualitas maka perusahaan atau badan tersebut akan mempermudah manajemen melakukan keputusan dan akan mempermudah pihak petugas pajak dalam hal perpajakannya. Peran manajemen dalam hal pengambilan keputusan berdasarkan laporan-laporan perusahaan khususnya laporan keuangan adalah hal yang sangat penting. Laporan keuangan yang digunakan oleh manajemen untuk pengambilan keputusan harus memenuhi kriteria laporan keuangan yaitu relevan, andal (akurat) dan tepat waktu (Sanjaya, 2017).

Informasi laporan keuangan sangat penting untuk menentukan seberapa besar pajak yang ditanggung badan, sehingga laporan keuangan harus memliki Kualitas dalam penyajiannya. Laporan keuangan akan meperlihatkan kinerja perusahaan serta perubahan posisi keuangan perusahaan sehingga akan bermanfaat dalam pengambilan kebijakan manajemen perusahaan, untuk menentukan strategi kedepan. Informasi yang bermanfaat adalah informasi yang memliki kualitas $\mathrm{m}$ (reliable). Kualitas informasi memiliki aspek jujur (faithful represetation) apa yang dituangkan secara jujur dan wajar. Salah satu faktor yang mempengaruhi kualitas laporan keuangan adalah masalah sistem informasi akuntansi.

Untuk menghasilkan kualitas informasi keuangan yang sesuai dengan karakteristik kualitatif laporan keuangan sesuai dengan PP No. 71 Tahun 2010, maka diperlukan adanya sistem informasi akuntansi (Yusup, 2017). Akuntansi merupakan hal yang penting dalam sistem perpajakan, dalam pelaksanaanya penerapan Sistem
Informasi Akuntansi sangat dibutuhkan untuk mencapai tingkat Kualitas dalam membuat laporan keuangan. Hal ini menggambarkan bahwa SPT karena kendala laporan akuntansi yang tidak memenuhi standar, sehingga menimbulkan dampak negatif berupa tidak diperolehnya kualitas informasi akuntansi keuangan secara cepat dan akurat. (Mulyadi, 2012) menerangkan bahwa Kualitas informasi akutanasi yang tertuang dalam laporan keuangan supaya bermanfaat untuk kebijakan manajemen atau pengambilan keputusan maka harus memliki aspek didalamnya relevan, kualitas $\mathrm{n}$, komparabilitas dan konsisten. Jika aspek-aspek tersebut tidak diperhatikan dalam penyajian alaporan keuangan, maka informasi yang didalamnya kurang handal atau kurang berkualitas.

Salah satu faktor yang dapat mempengaruhi penyajian laporan keuangan memliki kualitas adalah penerapan sistem informasi akutansi. Pemanfaat teknologi informasi dalam penyusuanan laporan keuangan akan berdampak pada keteatan waktu penyajian dan tingkat ketelitian dalam memasukkan anggka dalam laporan keuangan. Semakin cepat pengelolaan data yang akan disajikan perusahaan akan semakin cepat memberikan informasi tentang perusahaan. Maka dengan dukungan sistem informasi akuntansi di suatu perusahaan, maka akan berpengaruh pada ketepatan dalam penyusunan laporan keuangan. Peraturan Pemerintah No. 71 Tahun 2010 tentang Standar Akuntansi, yakni: i) relevan, ii) andal, iii) dapat dibandingkan, iv) dapat dipahami. Standar Akuntansi diatur dalam Peraturan Pemerintah No.71 tahun 2010, sebagai ganti prinsip-prinsip akuntansi dalam penyusunan dan penyajian laporan keuangan.

Prinsip-prinisp akuntansi dalam 
SAK (2016) menyebutkan Standar Akuntnasi Keuangan memliki tujuan agar pembuatan laporan keuangan perusahaan atau badan dapat seragam atau sama dalam kerangka prosedur serta tata cara penyusunananya. Standar Akuntansi Keuangan (SAK) terdiri dari IAS, IFRS, ETAP, GAAP. Penerapan standar akuntanasi yang telah diataur didalam IAI (2016) mneyatakan bahwa SAK dalam perusahaan atau badan harus mengikutsertakan laporan keuanganya dalam Standar Akuantansi yang sudah ditentukan. Pada PSAK-IFRS, SAK ETAP ditetapkan oleh Dewan Standar Akuntansi keuangang Ikatan Akuntansi Indonesia. PSAK Syariah diterbitkan oleh Dewan Akuntansi Syariah sedangkan SAP oleh Komite Standar Akuntansi Pemerintah. Dalam proses akuntansi, seorang akuntansi, seorang akuntansi harus menjalankannya sesuai standar akuntansi yang berlaku. Standar akuntansi keuangan (SAK) adalah metode dan format baku dalam penyajian informasi laporan keuangan suatu kegiatan bisnis. Pada kenyataannya, hanya perusahaanperusahaan yang berskala besar yang mampu menyusun dan menyajikan laporan keuangan berdasarkan PSAK Umum, hal ini dikarenakan dibutuhkannya biaya yang besar. Sedangkan badan-badan usaha seperti UMKM dan Badan Menegah Kebawah masih kesulitan melakukan standar akuntansi sesuai peraturan yang diajurkan dalam SAK.

\section{LANDASAN TEORI DAN PENGEMBANGAN HIPOTESIS Kualitas Laporan Keuangan}

Kualitas laporan keuangan memiliki peran penting terhadap pihak-pihak yang berkepentingan. Hal ini karena laporan keuangan mengandung informasi tentang posisi keuangan, kinerja perusahaan serta pertumbuhan posisis keuangan perusahaan. Pentingnya informasi laporan keuangan, maka diperlukan penyajian laporan keuangan secara berkualitas. Menurut (Sanjaya, 2017) mengatakan penyajian laporan keuangan yang dibuat manajer atau pimpinan perusahaan yang dipercayakan kepadanya oleh pemilik, pemerintah atau (kantor pajak), kreditor (bank dan lembaga keuangan lainnya) dan pihakpihak yang berkepentingan. Menurut SAK (2014) Kesalahan dalam membaca laporan keuangan bisa menyebabkan kekeliruan dalam pengambilan keputusan. Pernyataan standar akuntansi keuangan (SAK) nomor 1 (2014) mengungkapkan : Tujuan laporan keuangan untuk memberikan informasi tentang posisi bagian sebagian besar kalangan pengguna laporan keuangan dalam rangka membuat keputusankeputusan ekonomi serta menunjukkan pertanggung jawaban (stewardship) manajemen atas penggunaan sumbersumber daya yang dipercayakan kepada mereka.".

\section{Penerapan Sistem Informasi Akuntansi}

Sistem informasi akuntansi adalah sistem yang mengumpulkan dan memproses transaksi-tansaksi data dan menyampaikan informasi keuangan kepada pihak-pihak tertantu (Weygandt E. Kieso, Donald, Jerry J, 2017). Sistem informasi akuntansi (SIA) adalah sitem berbasis komputer yang dirancang untuk mentraformasi data akuntansi menjadi informasi (Bodnar, George H. dan Hopwood, 2011). SIA (Sistem Informasi Akuntansi) adalah perkumpulan datadata keuangan yang dirpoeses melalui transkasi data dan oautput informasinya disampaikan kepada pihak-pihak tertentu. Sistem informasi akuntansi mempunyai bagian yang sangat penting dalam suatu perusahaan dan organisasi. 
Standar Akuntansi Keuangan

Standar Akuntansi Keuangan (SAK) adalah suatu kerangka dalam prosedur pembuatan laporan keuangan agar terjadinya keseragaman dalam penyajian laporan keuangan. Standar Akuntansi Keuangan (SAK) merupakan hasil perumusan Komite Prinsipil Akuntansi Indonesia pada tahun 1994 menggantikan Prinsip Akuntansi Indonesia tahun 1984. SAK di Indonesia merupakan terapan dari beberapa standar akuntansi yang ada seperti, IAS, IFRS, ETAP, GAAP. Selain itu juga PSAK syariah dan juga SAP

\section{Pemanfaatan Teknologi Informasi}

Pemanfaatan teknologi informasi yang dimaksud adalah penggunaan aplikasi komputer akuntansi pada pengelolaan keuangan perusahaan atau badan. Penerapan sistem komputerisasi akuntansi pada perusahaan atau badan usaha akan mempercepat proses pencatatan, penyajian, analisa dan laporan keuangan perusahaan, karena aplikasi komputer akuntansi diciptakan untuk mengotorisasi transaksi-transaksi akuntansi ke dalam sebuah laporan dan analisa laporan untuk mendukung pengambilan keputusan sehubungan dengan keadaan keuangan dalam suatu periode akuntansi. Pemanfaatan teknologi informasi merupakan penggunaan secara optimal komputer, perangkat lunak, database, jaringan, electronic commerce, dan jenis lainnya yang berhubungan dengan teknologi informasi (Wilkinson et al, 2000). Pemanfaatan teknologi mencakup adanya (a) pengolahan data. Pengolahan informasi, sistem manajemen dan proses kerja secara elektronik dan (b) pemanfaatan kemajuan teknologi informasi agar pelayanan publik dapat diakses secara mudah dan murah oleh masyarakat (Hamzah, 2009).

\section{Pengaruh Penerapan Sistem Informasi Akuntansi Terhadap Kualitas Laporan Keuangan}

Penerapan sistem informasi akuntansi yang baik dan benar, akan membawa dampak pada penyajian laporan keuangan yang berkualitas dan memliki aspek kualitas $m$ yang dapat digunakan sebagai informasi pada pihak yang berkepentingan. Prosedur akutanasi yang telah diatur dalam standar kautnasi perlu diikuti secara makismal untuk supaya meperoleh hasil lapoaran keuangan yang berkualitas (Mas'ut, 2018). Organisasi bebas merancang dan menerapkan berbagai prosedur yang diharapkan dapat menghasilkan informasi yang dibutuhkan. Laporan keuangan yang memperhatikan aspek-aspek kualitas laporan keuangakan memliki informasi yang handal dan dapat memengaruhi keputusan pengguna dengan membantu mereka mengevaluasi peristiwa masa lalu atau masa kini, dan memprediksi masa depan, serta menegaskan atau mengoreksi hasil evaluasi mereka masa lalu. Menurut (Mardiasmo, 2016) Sistem Informasi Akuntansi (SIA) adalah pengelolaan sistem yang menghasilakn informasi menganai akutansi. Sedangkan informasi yang dikandung dalam akutansi juga sebuah informasi. Sistem pemrosesan transaksi adalah sebuah sistem yang mejalankan pencatatan secara rutin dari trasaksi harian. Sistem buku besar/pelaporan keuangan adalah sistem yang menghasilkan laporan keuangan, seperti laporan laba/rugi, neraca, arus kas, pengembalian pajak. Menurut Nadir Rasyidah, (2017), Penerapan Sisitem Informasi yang diterapakan dalam laporan keuangan mampu mepercepat pekerjaan dan ketelitian sehingga lebih tepat waktu dalam penyajiannya. 
Berdasarkan uraian diatas, maka dapat dihipotesisiskan:

Hipotesis 1: Terdapat pengaruh antara penerapan sistem informasi terhadap Kualitas laporan keuangan

\section{Pengaruh Standar Akuntansi Keuangan Terhadap Kualitas Laporan Keuangan}

Salah satu faktor yang mempengaruhi kualitas laporan keuangan adalah standar yang digunakan. Hal tersebut didukung oleh tujuan dari standar akuntansi yaitu menghasilkan informasi keuangan yang diharapkan mempunyai sifat jelas, konsisten, terpercaya dan dapat diperbandingkan (Bodnar, George $\mathrm{H}$. dan Hopwood, 2011). Dengan diterapkannya SAK, diharapkan kualitas laporan keuangan yang disusunnya akan meningkat. Untuk menilai kualitas laporan keuangan dapat dilihat dari karakteristik kualitatif yang harus ada dalam laporan keuangan. Agar bermanfaat, informasi harus relevan untuk memenuhi kebutuhan pengguna dalam proses pengambilan keputusan. Peneliti terdahulu (Yusup, 2017), Standar Akuntansi secara signifikan mempengaruhi kualitas laporan keuangan. Laporan keuangan yang dikerjakan sesuai standar yang ditetapkan berpengaruh terhadap kualitas laporan keuangan. Peneliti lain (Aditya, 2017), juga menyatakan bahwa standar akuntansi keuangan berpengaruh terhadap kualitas laporan keuangan.

Kualitas laporan keuangan akan memliki informasi yang relevan jika didalamnya mengandung informasi yang dapat digunakan sebagai keputusan ekonomi pengguna. Pentingnya kualitas informasi yang ditampung dalam laporan keuangan adalah kemudahannya untuk segera dapat dipahami oleh pengguna. Untuk maksud ini, pengguna diasumsikan memiliki pengetahuan yang memadai tentang aktivitas ekonomi dan bisnis, akuntansi, serta kemauan untuk mempelajari informasi dengan ketekunan yang wajar. Agar bermanfaat, informasi juga harus andal. Informasi merniliki kualitas andal jika bebas dari pengertian yang menyesatkan, kesalahan material, dan dapat diandalkan penggunannya sebagai penyajian yang jujur dari yang seharusnya disajikan atau yang secara wajar diharapkan dapat disajikan. Berdasarkan uraian diatas, maka dapat dihipotesisiskan:

Hipotesis 2: Terdapat pengaruh positif antara Standar Akuntansi Keuangan terhadap Kualitas laporan keuangan

\section{Pengaruh Pemanfaat Teknologi Informasi Terhadap Kualitas Laporan Keuangan}

Teknologi merupakan salah satu komponen yang mempengaruhi perusahaan yang kompleks. Oleh karena itu, pemanfaatan teknologi dalam hal ini aplikasi komputer akuntansi sangat penting dalam membantu penyusunan laporan keuangan yang berbasis akrual dengan efektif, efisien, dan ekonomis berdasarkan standar akuntansi pemerintahan. Pemanfaatan teknologi informasi merupakan penggunaan secara optimal komputer, perangkat lunak, database, jaringan, electronic commerce, dan jenis lainnya yang berhubungan dengan teknologi informasi (Wilkinson et al, 2000). Pemanfaatan teknologi mencakup adanya (a) pengolahan data. Pengolahan informasi, sistem manajemen dan proses kerja secara elektronik dan (b) pemanfaatan kemajuan teknologi informasi agar pelayanan publik dapat diakses secara mudah dan murah oleh masyarakat Lindawati dan Salamah (2012). Berdasarkan uraian diatas, maka dapat dihipotesisiskan: 
Hipotesis 3: Terdapat pengaruh antara

terhadap Kualitas laporan keuangan

Pemanfaatan Teknolofi Informasi

\section{Kerangka Pikir Penelitian}

Berdasarkan pengembangan hipotesis dari hasil penelitian terdahulu diatas, maka dapat disusun kerangka pemikiran teoritis sebagai berikut;

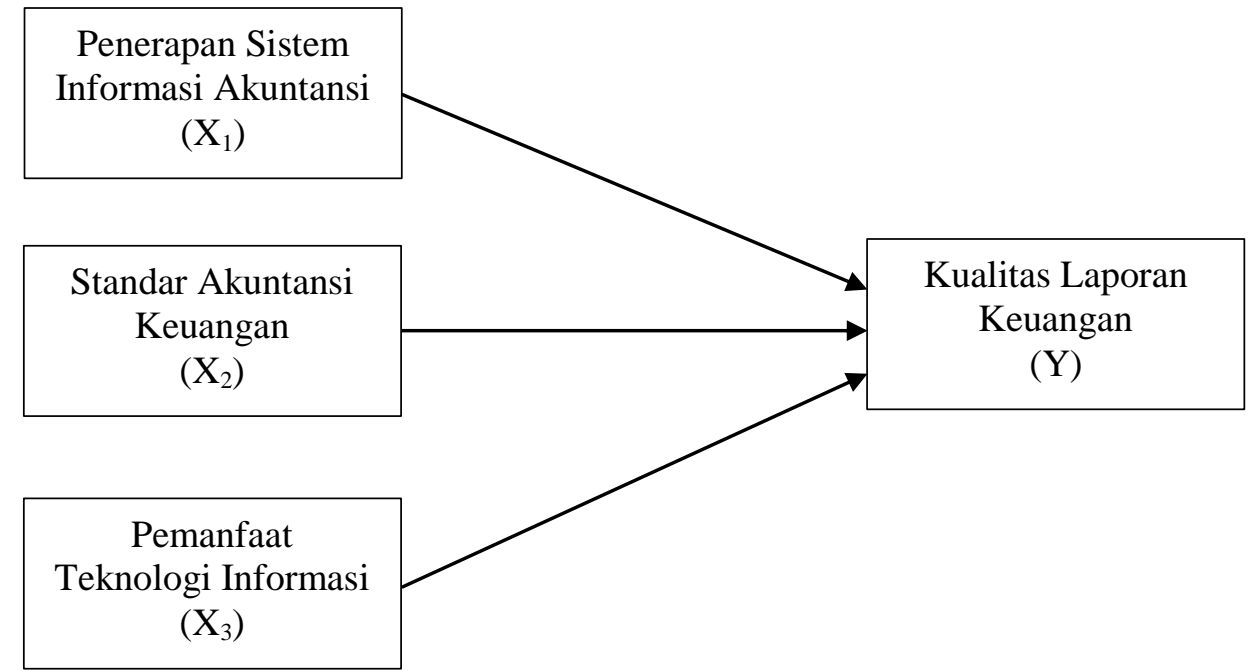

Gambar 1

Kerangka Berpikir

\section{METODOLOGI PENELITIAN \\ Rancangan Penelitian}

Rancangan Peneltian dilakukan melalui serangkaian tahapan yaitu lokasi penelitian di Kota Yogyakarta, sampel penelitian akan ditentukan berdasarkan purposive sampling. Kriteria responden yang dituju kemudian diserbarkan kuesioner yang berisi sejumlah pertanyaaan dari keempat variabel penelitian yaitu pemanfaatan teknologi informasi, kompetensi sumber daya manusia, standar akuntansi berbasis akrual, dan kualitas laporan keuangan pemerintah daerah. Data yang terkumpul kemudian dilakukan pengujian yaitu uji validitas dan uji reliabilitas untuk instrumen pertanyaan dan pengujian terhadap hipotesis yang diajukan.

\section{Teknik Analisa Data}

Teknik analisis data yang digunakann adalah menggunakan SPSS 20.0. Langkah yang digunakan untuk menganalisis data yaitu dengan statistic deskriptif, uji asumsi klasik (uji multikoliniearitas, uji heterokesdastisitas, uji normalitas), analisis regresi berganda dan uji hipotesis. 
HASIL DAN PEMBAHASAN

1. Uji Instrumen Penelitian

Tabel 1.

Uji Instrumen Penelitian

\begin{tabular}{|c|c|c|c|c|c|c|}
\hline Variabel & \multicolumn{4}{|c|}{ Validitas } & \multicolumn{2}{|c|}{ Reliabilitas } \\
\hline & $\begin{array}{l}\text { No } \\
\text { Item }\end{array}$ & $r$ hitung & $\mathrm{r}$ tabel & Ket & $\begin{array}{c}\text { Cronbach's } \\
\text { Alpha }\end{array}$ & Ket \\
\hline \multirow{10}{*}{$\begin{array}{l}\text { Kualitas } \\
\text { Laporan } \\
\text { Keuangan }\end{array}$} & 1 & 0,483 & 0.1654 & Valid & \multirow[t]{10}{*}{0,785} & \multirow[t]{10}{*}{ Reliabel } \\
\hline & 2 & 0,506 & 0.1654 & Valid & & \\
\hline & 3 & 0,517 & 0.1654 & Valid & & \\
\hline & 4 & 0,449 & 0.1654 & Valid & & \\
\hline & 5 & 0,462 & 0.1654 & Valid & & \\
\hline & 6 & 0,390 & 0.1654 & Valid & & \\
\hline & 7 & 0,441 & 0.1654 & Valid & & \\
\hline & 8 & 0,431 & 0.1654 & Valid & & \\
\hline & 9 & 0,473 & 0.1654 & Valid & & \\
\hline & 10 & 0,412 & 0.1654 & Valid & & \\
\hline \multirow{5}{*}{$\begin{array}{l}\text { Penerapan } \\
\text { Sistem } \\
\text { Informasi } \\
\text { Akuntansi }\end{array}$} & 1 & 0,548 & 0.1654 & Valid & \multirow[t]{5}{*}{0,734} & \multirow[t]{5}{*}{ Reliabel } \\
\hline & 2 & 0,416 & 0.1654 & Valid & & \\
\hline & 3 & 0,639 & 0.1654 & Valid & & \\
\hline & 4 & 0,436 & 0.1654 & Valid & & \\
\hline & 5 & 0,445 & 0.1654 & Valid & & \\
\hline \multirow{8}{*}{$\begin{array}{c}\text { Standa } \\
\text { Akuntansi } \\
\text { Keuangan }\end{array}$} & 1 & 0,512 & 0.1654 & Valid & \multirow[t]{8}{*}{0,771} & \multirow[t]{8}{*}{ Reliabel } \\
\hline & 2 & 0,456 & 0.1654 & Valid & & \\
\hline & 3 & 0,537 & 0.1654 & Valid & & \\
\hline & 4 & 0,444 & 0.1654 & Valid & & \\
\hline & 5 & 0,531 & 0.1654 & Valid & & \\
\hline & 6 & 0,387 & 0.1654 & Valid & & \\
\hline & 7 & 0,375 & 0.1654 & Valid & & \\
\hline & 8 & 0,547 & 0.1654 & Valid & & \\
\hline \multirow{7}{*}{$\begin{array}{l}\text { Pemanfaatan } \\
\text { Sistem } \\
\text { Teknologi } \\
\text { Informasi }\end{array}$} & 1 & 0,443 & 0.1654 & Valid & \multirow[t]{7}{*}{0,797} & \multirow[t]{7}{*}{ Reliabel } \\
\hline & 2 & 0,461 & 0.1654 & Valid & & \\
\hline & 3 & 0,540 & 0.1654 & Valid & & \\
\hline & 4 & 0,492 & 0.1654 & Valid & & \\
\hline & 5 & 0,660 & 0.1654 & Valid & & \\
\hline & 6 & 0,658 & 0.1654 & Valid & & \\
\hline & 7 & 0,467 & 0.1654 & Valid & & \\
\hline
\end{tabular}


Hasil uji validitas mengenai variabel semua item pertanyaan masing-msing variabel valid karena nilai $r$ hitung $>r$ tabel, dan masing-msing variabel nilai Cronbach's alpha menunjukkan nilai yang reliabel karena nilai Cronbach's alpha $>0,60$.

\section{Uji Asumsi Klasik}

a. Uji Normalitas

1) Uji Grafik

Berdasarkan hasil olah data dapat dilihat uji grafik normalitas sebagai berikut:

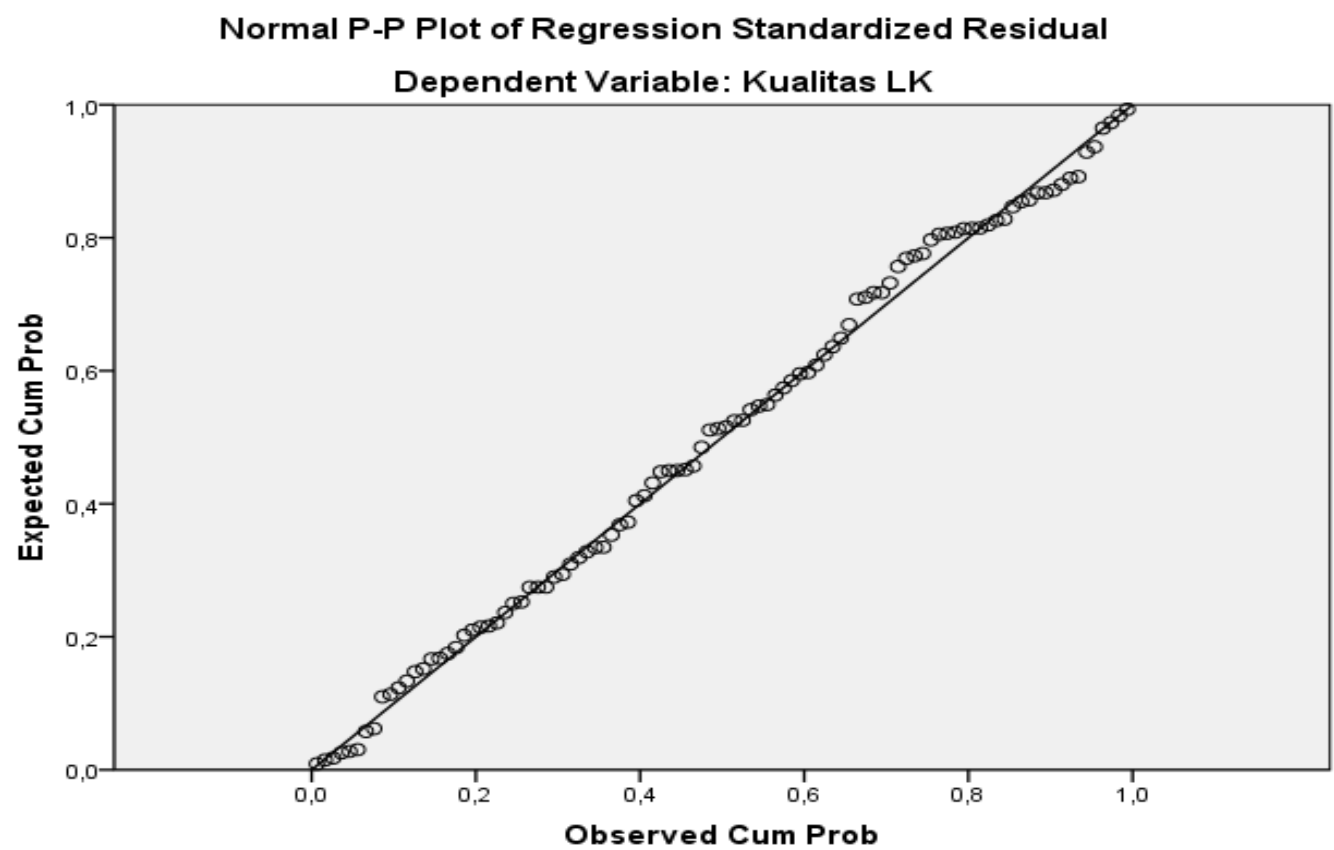

Gambar 1

Grafik Uji Normalitas

Berdasarkan grafik diatas dapat dilihat bahwa penyebaran data mendekati garis linier, sehingga dapat disimpulkan bahwa data berdistribusi normal.

2) Uji Statistik

Tabel 2.

Hasil Uji Normalitas

One-Sample Kolmogorov-Smirnov Test

\begin{tabular}{|ll|r|}
\hline & & $\begin{array}{c}\text { Unstandardized } \\
\text { Residual }\end{array}$ \\
\hline N & Mean & 100 \\
Normal Parameters & a,b &, 0000000 \\
Most Extreme & Std. Deviation & 3,67651023 \\
Differences & Absolute &, 052 \\
& Positive &, 045 \\
& Negative &,- 052
\end{tabular}


Kolmogorov-Smirnov Z

a. Test distribution is Normal.

b. Calculated from data.

Tabel 2. menunjukkan bahwa nilai Kolmogrov-Smirnov $Z$ sebesar 0,524 dan nilai Asymp. Sig. (2-tailed) sebesar 0,946 yang diperoleh model regresi lebih dari $\alpha(0,05)(0,946>0,05)$, berarti berdistribusi normal.

\section{b. Uji Multikolinearitas}

Tabel 3.

Hasil Uji Multikolinieritas

\begin{tabular}{|ll|r|r|}
\hline \multicolumn{2}{|l|}{ Model } & \multicolumn{2}{|c|}{ Collinearity Statistics } \\
\cline { 3 - 4 } & & Tolerance & \multicolumn{1}{c|}{ VIF } \\
\hline 1 & (Constant) & & \\
& Penerapan SIA &, 897 & 1,115 \\
& SAK &, 897 & 1,115 \\
& Pemanfaatan TI &, 992 & 1,008 \\
\hline
\end{tabular}

Tujuan uji multikolinieritas adalah untuk menguji apakah pada model regresi di atas ditemukan adanya korelasi yang kuat antar variabel independen atau bebas yaitu pemahaman peraturan perpajakan, penerapan sistem informasi akuntansi dan standar akuntansi keuangan. Dari hasil olah data tersebut, dapat dilihat nilai VIF semua variabel memiliki nilai VIF $<5$, sehingga model regresi tersebut di atas tidak terjadi multikolinieritas sehingga model regresinya dapat digunakan. Sedangkan nilai tolerance lebih dari 0,1 .

\section{c. Uji Heteroskedastisitas}

Heteroskedastisitas mengandung pengertian bahwa variasi residual tidak sama untuk semua pengamatan.

1) Metode Grafik

Adapun grafik tersebut dapat dilihat berikut. 
Scatterplot

Dependent Variable: Kualitas LK

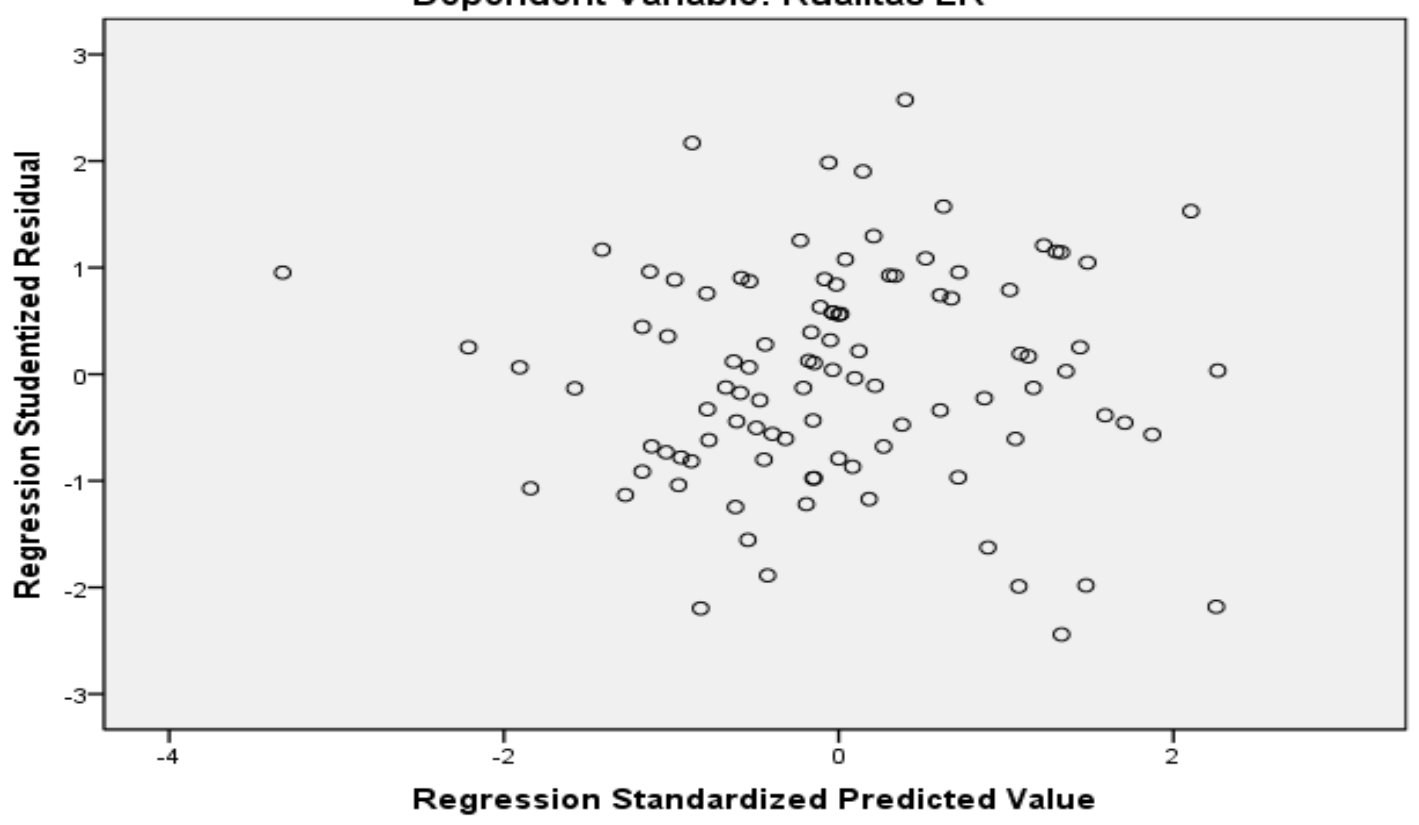

Gambar 2.

Grafik Uji Heteroskedastisitas

Berdasarkan grafik di atas, maka penyebaran data pada grafik terlihat menyebar dan tidak membentuk pola. Pengujian lebih lanjut ada tidaknya Heteroskedastisitas dilakukan dengan uji statistik metode Gleser.

2) Metode Statistik

Tabel 4.

Nilai Uji Heteroskedastisitas

Coefficients

\begin{tabular}{|c|c|c|c|c|c|c|}
\hline \multirow{2}{*}{\multicolumn{2}{|c|}{ Model }} & \multicolumn{2}{|c|}{$\begin{array}{c}\text { Unstandardized } \\
\text { Coefficients }\end{array}$} & \multirow{2}{*}{$\begin{array}{c}\text { Standardized } \\
\text { Coefficients } \\
\text { Beta }\end{array}$} & \multirow[b]{2}{*}{$\mathrm{t}$} & \multirow[b]{2}{*}{ Sig. } \\
\hline & & B & $\begin{array}{l}\text { Std. } \\
\text { Error }\end{array}$ & & & \\
\hline \multirow[t]{4}{*}{1} & (Constant) & ,258 & 2,866 & & ,090 & ,928 \\
\hline & Penerapan SIA & ,129 & 094 & , 14. & 1,374 & , 173 \\
\hline & SAK & ,077 & ,068 &, $11 \xi$ & 1,137 & ,258 \\
\hline & Pemanfaatan TI &,- 085 &, 058 &,- 146 & $-1,472$ & 144 \\
\hline
\end{tabular}

a. Dependent Variable: Abs_Residual 
Dari tabel 4 diperoleh bahwa ada semua variabel bebas mempunyai nilai probabilitas yang lebih besar dari taraf signifikan 0,05 , sehingga dapat disimpulkan bahwa dalam model regresi tidak terjadi gejala Heteroskedastisitas.

\section{Analisis Data}

\section{a. Analisis Regresi Berganda}

Tabel 5.

Hasil Pengolahan Regresi Berganda

\begin{tabular}{|ll|r|r|r|r|r|}
\hline \multirow{2}{*}{ Model } & \multicolumn{2}{|c|}{$\begin{array}{c}\text { Unstandardized } \\
\text { Coefficients }\end{array}$} & $\begin{array}{c}\text { Standardized } \\
\text { Coefficients }\end{array}$ & & \\
\cline { 2 - 5 } & \multicolumn{1}{|c|}{ B } & \multicolumn{1}{c|}{ Std. } & & \\
& & Error & Beta & \multicolumn{1}{c|}{$\mathrm{t}$} & Sig. \\
\hline \multirow{2}{*}{1} & (Constant) & 11,691 & 5,032 & & 2,324 &, 022 \\
& Penerapan SIA &, 553 &, 165 &, 311 & 3,352 &, 001 \\
& SAK &, 320 &, 119 &, 248 & 2,678 &, 009 \\
& Pemanfaatan TI &, 265 &, 101 &, 231 & 2,618 &, 010 \\
\hline
\end{tabular}

Berdasarkan tabel 5, maka dapat diperoleh persamaan regresi sebagai berikut: $Y=11,691+0,553 X_{1}+0,320 X_{2}+0,265 X_{3}+$ error

Dari persamaan regresi linear berganda diatas dapat dijelaskan sebagai berikut:

$\mathrm{b}_{0}=11,691$ artinya jika nilai penerapan sistem informasi akuntansi, standar akuntansi keuangan dan pemanfaatan teknologi informasi sama dengan nol (0), maka kualitas laporan keuangan nilainya sebesar 11,691.

$\mathrm{b}_{1}=0,553$ artinya jika penerapan sistem informasi akuntansi mengalami kenaikan sebesar satu satuan maka kualitas laporan keuangan naik sebesar 0,553 satuan dengan asumsi variabel lain konstan.

$\mathrm{b}_{2}=0,320$ artinya jika standar akuntansi keuangan mengalami kenaikan sebesar satu satuan maka kualitas laporan keuangan naik sebesar 0,320 satuan dengan asumsi variabel lain konstan.

$\mathrm{b}_{3}=0,265$ artinya jika pemanfaatan teknologi informasi mengalami kenaikan sebesar satu satuan maka kualitas laporan keuangan naik sebesar 0,265 satuan dengan asumsi variabel lain konstan.

\section{b. Koefisien Determinasi}

Tabel 6.

Hasil Analisis Koefisien Determinasi $\left(\mathbf{R}^{2}\right)$

Model Summary ${ }^{\mathbf{b}}$

\begin{tabular}{|l|r|r|r|r|}
\hline Model & \multicolumn{1}{|c|}{$\mathrm{R}$} & R Square & \multicolumn{1}{c|}{$\begin{array}{c}\text { Adjusted R } \\
\text { Square }\end{array}$} & $\begin{array}{c}\text { Std. Error of } \\
\text { the Estimate }\end{array}$ \\
\hline &, $511^{\mathrm{a}}$ &, 261 &, 238 & 3,73351 \\
\hline
\end{tabular}

a. Predictors: (Constant), Pemanfaatan TI, Penerapan SIA, SAK 
Model Summary ${ }^{b}$

\begin{tabular}{|l|r|r|r|r|}
\hline Model & \multicolumn{1}{|c|}{$\mathrm{R}$} & R Square & \multicolumn{1}{c|}{$\begin{array}{c}\text { Adjusted R } \\
\text { Square }\end{array}$} & $\begin{array}{r}\text { Std. Error of } \\
\text { the Estimate }\end{array}$ \\
\hline &, $511^{\mathrm{a}}$ &, 261 &, 238 & 3,73351 \\
\hline
\end{tabular}

a. Predictors: (Constant), Pemanfaatan TI, Penerapan SIA, SAK

b. Dependent Variable: Kualitas LK

Berdasarkan perhitungan Tabel 6 diperoleh nilai Adjusted $\mathrm{R}^{2}=0,238$ atau $23,8 \%$, hal ini menunjukkan bahwa variasi Kualitas laporan keuangan (Y) yang dapat dijelaskan variabel penerapan sistem informasi akuntansi, standar akuntansi keuangan dan pemanfaatan teknologi informasi sebesar 23,8\%. Sedangkan sisanya sebesar 76,2\% dipengaruhi faktor lain.

\section{Uji Hipotesis}

a. Uji Signifikan Parsial (Uji T)

1) Pengujian H1: Penerapan Sistem Informasi Akuntansi berpengaruh Terhadap Kualitas laporan keuangan

Berdasarkan analisis ini uji t dilakukan pada derajat kebebasan $(\mathrm{n}-\mathrm{k}-1)=96$, dimana $\mathrm{n}$ adalah jumlah observasi dan $\mathrm{k}$ adalah jumlah variabel. Dan pada tingkat keyakinan $95 \%$ atau $\alpha=5 \%$. Berdasarkan hasil olah data variabel penerapan sistem informasi akuntansi thitung lebih besar dari t-tabel $(3,352>1,988)$ dengan probabilitas $(0,001)$ lebih kecil dari taraf signifikan 0,05 , artinya variabel penerapan sistem informasi akuntansi mempunyai pengaruh positif dan signifikan terhadap Kualitas laporan keuangan (Hipotesis 1 terbukti).

2) Pengujian H2: Standar Akuntansi Keuangan Berpengaruh Terhadap Kualitas laporan keuangan Berdasarkan analisis ini uji t dilakukan pada derajat kebebasan $(n-k-1)=96$, dimana $n$ adalah jumlah observasi dan $\mathrm{k}$ adalah jumlah variabel. Dan pada tingkat keyakinan 95\% atau $\alpha=5 \%$. Berdasarkan hasil olah data variabel standar akuntansi keuangan t-hitung lebih besar dari t-tabel $(2,678$ $>1,988$ ) dengan probabilitas $(0,009)$ lebih kecil dari taraf signifikan 0,05 , artinya variabel penerapan standar akuntansi keuangan mempunyai pengaruh positif dan signifikan terhadap Kualitas laporan keuangan (Hipotesis 2 terbukti).

3) Pengujian H3:

Pemanfaatan Teknologi Informasi Berpengaruh Terhadap Kualitas laporan keuangan

Berdasarkan analisis ini uji t dilakukan pada derajat kebebasan $(n-k-1)=96$, dimana $n$ adalah jumlah observasi dan $\mathrm{k}$ adalah jumlah variabel. Dan pada tingkat keyakinan $95 \%$ atau $\alpha=5 \%$. Berdasarkan hasil olah data variabel pemanfatn 
teknologi informasi t-hitung lebih besar dari t-tabel $(2,618$ $>1,988)$ dengan probabilitas $(0,010)$ lebih kecil dari taraf signifikan 0,05 , dengan

demikian variabel pemanfaatan teknologi informasi mempunyai pengaruh positif dan signifikan terhadap Kualitas laporan keuangan (hipotesi 3 terbukti).

b. Uji F

Berdasarkan hasil uji F dari olah data SPSS dapat dilihat pada tabel berikut:

Tabel 7.

Hasil Nilai Uji-F

ANOVA $^{\mathrm{b}}$

\begin{tabular}{|c|c|c|c|c|c|}
\hline Model & $\begin{array}{l}\text { Sum of } \\
\text { Squares }\end{array}$ & $\mathrm{df}$ & $\begin{array}{l}\text { Mean } \\
\text { Square }\end{array}$ & $\mathrm{F}$ & Sig. \\
\hline 1 Regression & 472,354 & 3 & 157,451 & 11,296 &, $000^{\mathrm{a}}$ \\
\hline Residual & 1338,156 & 96 & 13,939 & & \\
\hline Total & 1810,510 & 99 & & & \\
\hline
\end{tabular}

a. Predictors: (Constant), Pemanfaatan TI, Penerapan SIA, SAK

b. Dependent Variable: Kualitas LK

Berdasarkan analisis ini, uji F dilakukan pada tingkat keyakinan $95 \%$ atau $\alpha=$ $5 \%$ dengan derajat kebebasan pembilang $\mathrm{k}-1$, yaitu 3 dan derajat kebebasan penyebut n-k-1, yaitu 96 atau dapat dituliskan dengan $\mathrm{F} 0,05$; df $(3 ; 96)$. Dari hasil pengolahan data di atas diketahui bahwa nilai F-hitung adalah 11,296. Dengan nilai signifikan sebesar 0,000 , dan nilai F-tabel adalah 2,71. Dengan demikian dapat disimpulkan bahwa F-hitung > F-tabel dengan tingkat signifikan $0,000<0,05(\mathrm{p}<0,05)$, artinya variabel-variabel penerapan sistem informasi akuntansi, standar akuntansi keuangan dan pemaanfaatan teknologi informasi berpengaruh secara simultan terhadap Kualitas laporan keuangan.

\section{PEMBAHASAN}

\section{Pengaruh Penerapan Sistem Informasi Akuntansi Terhadap Kualitas Laporan Keuangan}

Hasil pembahsan dan analisis menemukan penerapan sistem informasi akuntansi memliki pengaruh positif dan signifikan terhadap kualitas laporan keuangan Wajib Pajak Badan. Hasil ini menunjukkan bahwa jika penerapan sistem informasi akuntansi meningkat atau semakin efektif, maka kualitas laporan keuangan semakin baik atau semakin berkualitas. Hal ini mendukung penelitia sebelumnya yang dilakukan oleh (Mas'ut, 2018) Prosedur akutanasi yang telah diatur dalam standar kautnasi perlu diikuti secara makismal untuk supaya meperoleh hasil lapoaran keuangan yang berkualitas. Penerapan sistem informasi akuntansi berpengaruh posiitif terhadap kualitas laporan keuangan. Hal ini sesuai pendapat (Mardiasmo, 2016) Sistem Informasi Akuntansi (SIA) adalah pengelolaan sistem yang menghasilakn informasi menganai akutansi, dimana informasi yang dikandung dalam akutansi merupakan informasi yang menadji indikator kualitas laporan keuangan.

$\begin{array}{lcr}\begin{array}{l}\text { Pengaruh } \\ \text { Keuangan }\end{array} & \begin{array}{c}\text { Standar } \\ \text { Terhadap }\end{array} & \begin{array}{r}\text { Akuntansi } \\ \text { Kualitas }\end{array} \\ \text { Laporan Keuangan } & \\ \text { Hasil } & \text { pembahasan } & \text { dan analisis } \\ \text { menemukan } & \text { Standar } & \text { Akuntansi }\end{array}$


Keuangan memiliki pengaruh positif dan signifikan terhadap kualitas laporan keuangan Wajib Pajak Badan. Hasil ini menunjukkan bahwa jika standar akuntansi keuangan meningkat atau semakin perusahaan dalam penyajian laporan keuangan sesuai dengan standar akuntansi keuangan yang ada, maka kualitas laporan keuangan semakin baik atau semakin berkualitas. Hal ini mendukung penelitia sebelumnya yang dilakukan oleh (Aditya, 2017) dan (Yusup, 2017), yang menyatakan Standar Akuntansi secara signifikan mempengaruhi kualitas laporan keuangan. Laporan keuangan yang dikerjakan sesuai standar yang ditetapkan berpengaruh terhadap kualitas laporan keuangan. Hal ini sesuai pendapat Belkaoui, (IAI, 2016). Dengan diterapkannya SAK, diharapkan Kualitas laporan keuangan yang disusunnya akan meningkat.

\section{Pengaruh Pemanfaatan Teknologi Informasi Terhadap Kualitas Laporan Keuangan}

Hasil pembahasan dan analisis menemukan pemanfaatan teknologi informasi memiliki pengaruh positif dan signifikan terhadap kualitas laporan keuangan Wajib Pajak Badan. Hasil ini menunjukkan bahwa jika pemanfaatan teknologi informasi meningkat atau semakin tinggi perusahaan atau badan dalam menerapkan teknologi inoformasi untuk mengerjakan laporan keuangan, maka akan mampu mepercepat pekerjaan penyususn lapran keuangan sehingga laporan keuangan akan daat disajikan secara tepat waktu dan memliki kualitas yang lebih baik. Hal ini mendukung penelitia sebelumnya yang dilakukan oleh Lindawati dan Salamah (2012). yang menyatakan bahwa pemanfaatan teknologi informasi akan mampu mempengaruhi kinerja keuangan dan kualitas laporan keuangan suatu perusahaan. Teknologi merupakan salah satu komponen yang mempengaruhi perusahaan yang kompleks. Oleh karena itu, pemanfaatan teknologi dalam hal ini aplikasi komputer akuntansi sangat penting dalam membantu penyusunan laporan keuangan yang berbasis akrual dengan efektif, efisien, dan ekonomis berdasarkan standar akuntansi pemerintahan.

\section{KESIMPULAN}

Penerapan sistem informasi akuntansi, standar akuntansi keuangan dan pemanfaaatan teknologi informasi secara parsial berpengaruh signifikan terhadap kualitas laporan keuangan. Secara simultan penerapan sistem informasi akuntansi, standar akuntansi keuangan dan pemanfaaatan teknologi informasi berpengaruh signifikan terhadap kualitas laporan keuangan. Pengaruh pemahaman penerapan sistem informasi akuntansi, standar akuntansi keuangan dan pemanfaaatan teknologi informasi terhadap Kualitas laporan keuangan sebesar 23,8\%. Sisanya dipengaruhi faktor lain yaitu sebesar $76,2 \%$, yang tidak dimasukan dalam penelitian ini. 


\section{Daftar Pustaka}

Aditya, S. (2017). Pengaruh Penerapan Standar Akuntansi Pemerintahan, Sistem Pengendalian Intern, Sistem Akuntansi Keuangan Daerah, Dan Sumber Daya Manusia Terhadap Kualitas Laporan Keuangan Pemerintah Daerah Dengan Komitmen Organisasi Sebagai Pemoderasi (Studi Pada SKPD Ka. JOM Fekon Vol.4 No.1.

Bodnar, George H. dan Hopwood, W. S. (2011). Sistem informasi Akuntansi. Jakarta: Salemba Empat,.

Kusuma, K. C. (2016). Pengaruh Kualitas Pelayanan Pajak, Pemahaman Peraturan Perpajakan Serta Sanksi Perpajakan Terhadap Kepatuhan Wajib Pajak Orang Pribadi Dalam Membayar Pajak Tahun 2014 (Studi Kasus pada Wajib Pajak yang Terdaftar di Kantor Pelayanan Penyuluhan dan Konsulta. Skripsi, Fakultas Ekonomi Universitas Negeri Yogyakarta.

Lindawati dan Irma Salamah (2012)." Pemanfaatan Sistem Informasi dan Teknologi Informasi Pengaruhnya Terhadap Kinerja Individual Karyawan yang berdampak pada kualitas laporan keuangan" Jurnal Akuntansi Dan Keuangan, Vol. 14, No. 1, Mei 2012: 56-68

Mardiasmo. (2016). Perpajakan Edisi Terbaru. Yogyakarta: penerbit andi Yogyakarta.

Mas'ut, dan M. A. (2018). Pengaruh Penerapan Sistem Informasi Akuntansi Terhadap Akuntabilitas Pendapatan Pajak Daerah Di Badan Pengelola Pajak Dan
Retribusi Kota Medan. Jurnal Riset Akuntansi Multiparadigma (JRAM), Vol. 5. No. 1.

Mulyadi. (2012). Sistem Akuntansi. Jakarta: Salemba Empat.

Nadir Rasyidah, dan H. (2017). Pengaruh Pemanfaatan Teknologi Informasi, Kompetensi Sumber Daya Manusia, terhadap Kualitas Laporan Keuangan Pemerintah Daerah Dengan Variabel Intervening Standar Akuntansi Pemerintahan Berbasis Akrual (Studi Empiris di PEMDA Kabupaten Barru). Online http://journal.feb.unmul.ac.id/inde x.php/AKUNTABEL /issue/view/78 AKUNTABEL Volume 14, No 1.

Susanto, A. (2014). Sistem Informasi Akuntansi. Bandung: Lingga Jaya.

Venkatesh, V. dkk. (2003). User Acceptance of Information Technoligy: Toward a Unified Views. MIS Quarterly, Volume 27.

Vina, R. (2015). Pengaruh Persepsi Atas Pp Nomor 46 Tahun 2013 Terhadap Kepatuhan Wajib Pajak. Jurnal Ilmu \& Riset Akuntansi Vol. 4 No. 9.

Wilkinson, Josep W. Et al. 2000. Accounting Information System Essential Concept and Application. 4 Edition, John Willey \& Sons Inc. New York-USA.

Yusup, K. (2017). Pengaruh Penerapan Standar Akuntansi Pemerintahan Dan Sistem Pengandalian Intern Terhadap Kualitas Laporan Keuangan (Studi Penelitian Pada Instansi Pemerintah Kota Bandung. Jurnal, Fakultas Ekonomi Universitas Komputer Indonesia. 